\title{
Combined NS5A \& NS5B Nucleotide Inhibitor Therapy for Patients with Chronic Hepatitis C with Stage 5 Chronic Kidney Disease on Hemodialysis
}

\author{
Prasanta DEBNATH, Sanjay CHANDNANI, Pravin RATHI, Sujit NAIR, Vinay PAWAR and Qais CONTRACTOR
}

Received: 6 September 2019 Accepted: 28 November 2019

ABSTRACT - Background - Hepatitis C virus (HCV) infection is the most common hepatotropic viral infection affecting the patients on maintenance hemodialysis. Treatment of chronic HCV infection in stage 4 and 5 CKD includes a combination of elbasvir/grazoprevir and glecaprevir/pibrentasvir, which are not available in many countries. Objective - Hence, we have conducted this study to look for the safety and efficacy of sofosbuvir combination therapy in this difficult to treat population. Methods - We conducted a single-center, prospective, open-label study in which Stage 5 CKD patients on maintenance hemodialysis with HCV infection. Total of 18 patients was included. sofosbuvir with daclatasvir or ledipasvir was used according to genotype for 12 weeks. HCV RNA, genotype, transient elastography (TE) was considered for every patient. HCV RNA was quantified at 4th week, 12th week and 12 weeks post-treatment to look for sustained virologic response (SVR 12). Results - Infection due to genotype 1 was seen in 12 (66.7\%) patients followed by genotype 3 in $4(22.3 \%)$ with each patient of genotype 2 and 5. The median value of HCV RNA was 2,35,000 IU/mL. On TE, all had liver stiffness of $<9.4 \mathrm{KPa}$. All patients had HCV RNA of $<15 \mathrm{IU} / \mathrm{mL}$ at 4 th and 12 th week of treatment and 12 weeks post-treatment. No significant change in hemoglobin, eGFR and liver stiffness was observed. Conclusion - Full dose sofosbuvir i.e. $400 \mathrm{mg}$, in combination with NS5A inhibitors daclatasvir or ledipasvir is found to be safe and effective in patients with end stage renal disease, who are on maintenance hemodialysis.

HEADINGS - Hepacivirus. Renal dialysis. Sofosbuvir. Elasticity imaging techniques.

\section{INTRODUCTION}

Hepatitis $\mathrm{C}$ virus (HCV) infection is the most common hepatotropic viral infection affecting the patients on maintenance hemodialysis (HD) ${ }^{(1)}$. The prevalence of HCV infection in chronic kidney disease (CKD) patients on maintenance HD is much higher than the general population ${ }^{(2-5)}$. This is mainly due to excessive exposure to blood products and nosocomial transmission of $\mathrm{HCV}$ infection in dialysis units ${ }^{(6)}$.

The prevalence of anti-HCV seropositivity is reported in up to $13.5 \%$ patients on HD but varies widely between $5 \%$ and $60 \%$ in various studies ${ }^{(5,7-9)}$. In India, prevalence of $\mathrm{HCV}$ in $\mathrm{HD}$ has been reported from $4.3 \%$ to $45 \%{ }^{(3,10)}$.

Following exposure to $\mathrm{HCV}$, acute hepatitis develops in around $20 \%$ of patients, with spontaneous resolution in $15 \%-45 \%$ of patients in first six months of exposure. The remainder, develop a chronic hepatitis that has an unpredictable course. Approximately 20\%-30\% of persons with chronic hepatitis will progress to cirrhosis over a 25-30 year period. Moreover, $\mathrm{HCV}$ infection is an independent risk factor for CKD and end-stage renal disease (ESRD) patients. The overall mortality in CKD patients with ESRD and co-existent $\mathrm{HCV}$ infection is found to be higher compared to non-infected patients ${ }^{(11)}$. Increased risk of graft loss, rejection and mortality has been found in post-kidney transplant patients with $\mathrm{HCV}$ infection ${ }^{(12)}$. A severe form of liver injury, fibrosing cholestatic hepatitis has been described in patients with chronic HCV infection, post renal transplant who are on immunosuppressants. Finally, effective anti-HCV treatment in chronic kidney disease patients may significantly reduce proteinuria and stabilize serum creatinine levels ${ }^{(13)}$.

The standard of care for HCV infection, until recently was treatment with interferons plus ribavirin. Moreover, the treatment options for HD patients were suboptimal and the response to these medications was not satisfactory. Casanovas-Taltavull et al. in their meta-analysis, showed that overall sustained virologic response (SVR) with interferon therapy was only $33 \%$, and pegylated interferons provided only a marginal benefit over the conventional therapy ${ }^{(14)}$. Ribavirin and interferon combination was used rarely in this special group of population, because of increased side effects like development of anemia.

Though the largest series showed an SVR of 97\% in treated patients, in further reports, SVR ranged between $7 \%$ and $71 \%{ }^{(15,16)}$.

Thus, available approved regimens are associated with poor tolerance, side effects, high dropout rates, and dismal SVR ${ }^{(17-22)}$. New medication is the need of the hour for this special population.

Availability of Directly Acting Anti-virals (DAA) for treatment of chronic hepatitis $\mathrm{C}$ infection has transformed the management of HCV infection. However, patients with severe renal insufficiency $\left(\mathrm{eGFR}<30 \mathrm{~mL} / \mathrm{min} / 1.73 \mathrm{~m}^{2}\right.$ ) including those on HD continue to be a difficult-to-treat cohort, as limited number of DAAs are available for treatment in this subgroup. The only FDA-approved all-oral regimens of DAAs for patients with severe renal disease includes elbasvir / grazoprevir and glecaprevir / pibrentasvir, which are also supported by both AASLD and EASL guidelines ${ }^{(23-26)}$. But unfortunately, these drugs are currently not available in many countries.

Declared conflict of interest of all authors: none

Disclosure of funding: no funding received

T.N.M.C \& B.Y.L Nair Charitable Hospital, Gastroenterology, Mumbai, India.

Corresponding author: Prasanta Debnath. E-mail: prasantad89@gmail.com 
Sofosbuvir, the pan-genotypic NS5B inhibitor is the backbone of DAA regimens available in India. Sofosbuvir metabolites are excreted mainly by the renal route, which is significantly increased in patients with eGFR $<30 \mathrm{~mL} / \mathrm{min} / 1.73 \mathrm{~m}^{2}$ or on maintenance $\mathrm{HD}^{(27,28)}$.

Studies from India and abroad with Sofosbuvir, either used in full dose i.e. $400 \mathrm{mg}$, or half dose i.e. $200 \mathrm{mg}$ or with alternate day regimen, in combination with NS5A inhibitors, in patients with ESRD has shown excellent results in terms of efficacy as well as safety.

Hence, this study was planned to assess safety and efficacy of combination therapy using sofosbuvir $400 \mathrm{mg}$ along with daclatasvir $60 \mathrm{mg}$ or ledipasvir $90 \mathrm{mg}$ based on genotype for treatment of chronic hepatitis $\mathrm{C}$ infection in ESRD patients on maintenance HD.

\section{METHODS}

We conducted a single center, prospective, open-label observational study in order to assess safety and efficacy of combination therapy of sofosbuvir $(400 \mathrm{mg})$ with daclatasvir $(60 \mathrm{mg})$ or ledipasvir $(90 \mathrm{mg}$ ) depending on Genotype, in patients with chronic hepatitis $C$ and CKD with eGFR less than $15 \mathrm{~mL} / \mathrm{min} / 1.73 \mathrm{~m}^{2}$ on HD. The study was conducted at tertiary care Hospital in Western India. Sofosbuvir was used along with daclatasvir in patients with HCV genotype 2 or 3 , and ledipasvir was used in patients with $\mathrm{HCV}$ genotype 1 or 5 infection. Eligibility criteria were adults (age $>18$ years), treatment naïve HCV infection of any genotype, on HD who were willing to take treatment as per protocol. A total of 19 patients were included. The study extended for a period of one and half years from January 2017 to July 2018. Ethical clearance has been taken from Institute Ethics Committee.

\section{Pre-treatment evaluation}

A complete clinical, laboratory and endoscopic evaluation was considered for every patient in the study group. Complete blood count, liver and renal function test, Quantitative HCV RNA using Taqman Real Time PCR technique with lower limit of quantification of $15 \mathrm{IU} / \mathrm{mL}$, along with genotype analysis was done and extent of liver disease was assessed by ultrasonography (USG) and transient elastography (TE, Fibroscan). The degree of underlying liver fibrosis was ascertained by TE which was considered after a session of HD. Depending on the liver stiffness measurement, patients were classified as having no, mild or moderate fibrosis [F0, $\mathrm{F} 1, \mathrm{~F} 2]<9.5 \mathrm{kPa}$, severe fibrosis or cirrhosis [F3, F4] $\geq 9.5 \mathrm{kPa}$.

Estimated Glomerular Filtration Rate (eGFR) was assessed by Modification of Diet in Renal disease (MDRD) equation and CKD staged according to Kidney Disease Improving Global Outcomes (KDIGO) guidelines.

We administered sofosbuvir (400 mg) combined with daclatasvir (60 mg) or ledipasvir $(90 \mathrm{mg}$ ) once daily for 12 weeks. On the day of dialysis, drug was administered after the HD session and on off dialysis day it was administered at the same time as on day of HD.

Complete blood count, liver function test and renal function test were checked for each patient weekly for two weeks, then at 4 th week followed by every month until completion of treatment and subsequently at 12 weeks after the end of treatment response (ETR). Hepatitis C viral load (Lower limit of detection of 15 $\mathrm{IU} / \mathrm{mL}$ ) was checked after four weeks of treatment, at the end of treatment (12 weeks), as well as at week 12 post-treatment for SVR 12. The virologic cure or SVR 12 was defined as undetectable HCV RNA 12 weeks after ETR ${ }^{(29,30)}$. Clinical record files were maintained for each patient which was duly filled at each visit and any side-effects as mentioned by patients were recorded.

\section{Statistical analysis}

Continuous variables were expressed as mean \pm SD or median (range) as appropriate and categorical variables were expressed as percentage. All statistical tests were 2-tailed, and results were compared using Paired $t$ test and Wilcoxon Signed Rank Test and was considered statistically significant with a $\mathrm{p}$ value of less than 0.05 . Statistical analysis was performed using the Statistical Package for Social Science (SPSS version 22.0; SPSS Inc., Chicago, IL, USA).

\section{RESULTS}

Between January 2017 to July 2018, a total of 19 patients with chronic hepatitis $C$ infection with ESRD on HD were included. All patients were explained about the treatment options and availability, along with side effect profile of existing drugs. Consent was taken from each patient before initiating treatment. However, one patient died within four weeks of initiation of therapy due to inadequate HD. Thus, 18 patients completed the study.

\section{Patient characteristics}

All were treatment naïve cases of chronic hepatitis C. None of the patients had history of renal transplant and none had concurrent HIV or hepatitis B infection. The causes of underlying CKD in the patients enrolled were diabetic kidney disease in $7(38.8 \%)$ patients, hypertensive nephropathy in $5(27.7 \%)$ and unidentified in remaining cases. All of the patients were on maintenance hemodialysis twice or thrice a week as advised.

Demographic and baseline characteristics are shown in the TABLE 1.

TABLE 1. Demographic, baseline characteristics of the patients.

\begin{tabular}{|c|c|}
\hline Total patients & 18 \\
\hline Age $($ mean $\pm S D)$ years & $39.4 \pm 8.3$ \\
\hline Male : Female & $14: 4$ \\
\hline \multicolumn{2}{|l|}{ Etiology of CKD } \\
\hline Diabetic kidney disease & 7 \\
\hline Hypertensive nephropathy & 5 \\
\hline Unidentified & 6 \\
\hline Hemoglobin $(\mathrm{g} / \mathrm{dL})$ mean $\pm \mathrm{SD}$ & $9.5 \pm 1.5$ \\
\hline Platelets count $\left(\times 10^{9} / \mathrm{L}\right)$ median (range) & $215(110-324)$ \\
\hline Total bilirubin $(\mathrm{mg} / \mathrm{dL})($ mean $\pm \mathrm{SD})$ & $0.63 \pm 0.2$ \\
\hline AST (U/L) median (range) & $33(20-36)$ \\
\hline ALT (U/L) median (range) & $33.5(13-74)$ \\
\hline Albumin $(\mathrm{g} / \mathrm{dL})($ mean $\pm \mathrm{SD})$ & $3.42 \pm 0.38$ \\
\hline Serum creatinine $(\mathrm{mg} / \mathrm{dL})$ mean $\pm \mathrm{SD}$ & $6.9 \pm 1.8$ \\
\hline HCV RNA (IU/mL) median (range) & $\begin{array}{c}2,35,000 \\
(13,845-2,60,00,000)\end{array}$ \\
\hline \multicolumn{2}{|l|}{ HCV genotype, n (\%) } \\
\hline 1 & $12(66.7 \%)$ \\
\hline 2 & $1(5.5 \%)$ \\
\hline 3 & $4(22.3 \%)$ \\
\hline 5 & $1(5.5 \%)$ \\
\hline Cirrhosis, n (\%) & 0 \\
\hline \multicolumn{2}{|l|}{ Liver stiffness measurement $(\mathrm{kPa})(\%)$} \\
\hline$<9.4$ & $18(100 \%)$ \\
\hline$>9.4$ & 0 \\
\hline
\end{tabular}

ALT: alanine transaminase; AST: aspartate transaminase; kPa: kilo Pascal. 


\section{Adverse events}

Almost every patient tolerated the drugs well. Only four patients had history of nausea and dyspepsia, two patients had fatigue and one had headache. None of them had deterioration of renal parameters and liver function test or worsening of anemia, or requirement of increased dosage of erythropoietin.

\section{Treatment discontinuation}

Two patients died during treatment course within four weeks of treatment initiation. Data of those patients were not enlisted during evaluation of results. None of the remaining patients had to be put off treatment as side-effects were minor.

\section{Laboratory parameters}

No significant change in pre-treatment and post-treatment levels of hemoglobin, bilirubin, aminotransferases, estimated Glomerular Filtration Rate (eGFR) and liver stiffness was observed (TABLE 2).

TABLE 2. Pre-treatment and Post-treatment assessment.

\begin{tabular}{|c|c|c|c|}
\hline Variables & $\begin{array}{c}\text { Pre- } \\
\text { treatment }\end{array}$ & $\begin{array}{c}\text { Post- } \\
\text { treatment }\end{array}$ & $P$-value* \\
\hline $\begin{array}{l}\text { Hemoglobin }(\mathrm{g} / \mathrm{dL}) \\
\text { mean } \pm \text { SD }\end{array}$ & $9.5 \pm 1.5$ & $9.6 \pm 1.3$ & 0.429 \\
\hline $\begin{array}{l}\text { Bilirubin }(\mathrm{mg} / \mathrm{dL}) \\
\text { mean } \pm \mathrm{SD}\end{array}$ & $0.63 \pm 0.2$ & $0.58 \pm 0.2$ & 0.534 \\
\hline $\begin{array}{l}\text { AST, U/L, median } \\
\text { (Range) }\end{array}$ & $33(20-36)$ & $31.4(24-38)$ & 0.528 \\
\hline $\begin{array}{l}\text { ALT, U/L, median } \\
\text { (Range) }\end{array}$ & $33.5(13-74)$ & $26.9(22-44)$ & 0.237 \\
\hline $\begin{array}{l}\text { Albumin, }(\mathrm{gm} / \mathrm{dL}) \\
\text { mean } \pm \mathrm{SD}\end{array}$ & $3.42 \pm 0.38$ & $3.47 \pm 0.21$ & 0.781 \\
\hline $\begin{array}{l}\text { Serum creatinine }(\mathrm{mg} / \\
\mathrm{dL}) \text { mean } \pm \mathrm{SD}\end{array}$ & $6.9 \pm 1.8$ & $6.8 \pm 1.5$ & 0.861 \\
\hline $\begin{array}{l}\mathrm{eGFR}(\mathrm{mL} / \mathrm{min} / 1.73 \\
\left.\mathrm{m}^{2}\right) \text { mean } \pm \mathrm{SD}\end{array}$ & $9.6 \pm 3$ & $9.5 \pm 2.9$ & 0.788 \\
\hline HCV RNA (IU/mL) & $2,35,000$ & $<15$ & $<0.001$ \\
\hline $\mathrm{LSM}(\mathrm{kPa})$ mean $\pm \mathrm{SD}$ & $6.2 \pm 1.2$ & $6.1 \pm 1.1$ & 0.682 \\
\hline
\end{tabular}

ALT: alanine transaminase; AST: aspartate transaminase; eGFR: estimated glomerular filtration rate; LSM: liver stiffness measurement. $* P$ value $<0.05$ is significant.

\section{Virologic response}

The median value of HCV RNA before starting therapy was 2,35,000 IU/mL (Range: 13,845-2,60,00,000 IU/mL). All patients had HCV RNA level $<15 \mathrm{IU} / \mathrm{mL}$ after four weeks, at end of treatment i.e. 12 weeks and after 12 weeks of treatment completion i.e. SVR 12 (TABLE 3 ).

TABLE 3. Sustained virologic response rate by genotype and regimen used.

\begin{tabular}{lccc}
\hline Genotype & Regimen used & $\begin{array}{c}\text { Number of } \\
\text { patients }\end{array}$ & $\begin{array}{c}\text { SVR, } \\
\text { n (\%) }\end{array}$ \\
\hline 1 & $\begin{array}{c}\text { Sofosbuvir }(400 \mathrm{mg}) \\
\text { Ledipasvir }(90 \mathrm{mg})\end{array}$ & 12 & $12(100)$ \\
2 & $\begin{array}{c}\text { Sofosbuvir }(400 \mathrm{mg}) \\
\text { Daclatasvir }(60 \mathrm{mg})\end{array}$ & 1 & $1(100)$ \\
3 & $\begin{array}{c}\text { Sofosbuvir }(400 \mathrm{mg}) \\
\text { Daclatasvir }(60 \mathrm{mg})\end{array}$ & 4 & $4(100)$ \\
5 & $\begin{array}{c}\text { Sofosbuvir }(400 \mathrm{mg}) \\
\text { Ledipasvir }(90 \mathrm{mg})\end{array}$ & 1 & $1(100)$ \\
\hline
\end{tabular}

SVR: sustained virologic response.

\section{DISCUSSION}

The kidney is an important component of the HCV clinical syndrome, besides the liver, the musculoskeletal, immune and hematopoietic systems and the skin. The pathophysiology of kidney disease in $\mathrm{HCV}$ infection can be broadly categorized into following four mechanisms: (a) glomerular immune complex deposition; (b) direct viral invasion of the renal parenchyma; (c) renal complications of its extra renal (e.g. hepatic) manifestations; and (d) nephrotoxicity of drugs used for its treatment. It may cause acute kidney injury (AKI) as a part of systemic vasculitis and augments the risk of AKI due to other etiologies. It is responsible for mesangiocapillary or membranous glomerulonephritis and accelerates the progression of chronic kidney disease due to other causes.

Despite $\mathrm{HCV}$ infection being common in CKD patients particularly ESRD ones who are on regular hemodialysis, treatment options are limited. In patients with eGFR $<30 \mathrm{~mL} / \mathrm{min} / 1.73 \mathrm{~m}^{2}$ AASLD guidelines recommend using either elbasvir/grazoprevir (genotypes 1 and 4) or glecaprevir/pibrentasvir (pan-genotypic). However, none of these drugs are available in India ${ }^{(23)}$. The EASL guidelines continue to recommend pegylated interferon plus dose adjusted ribavirin for CKD patients infected with genotype 3 but tolerance and response rate is poor ${ }^{(30)}$.

Among direct acting anti-virals, sofosbuvir, a nucleotide analogue prodrug, pan-genotypic HCV NS5B polymerase inhibitor, forms the backbone of most anti-HCV containing regimens. It inhibits HCV RNA replicons in vitro, has high genetic barrier to resistance along with good patient tolerability with limited drug-drug interactions ${ }^{(22)}$. On oral administration, sofosbuvir is well absorbed with peak plasma concentration within half to two hours. It undergoes extensive hepatic metabolization with biotransformation in hepatocytes to form pharmacologically active nucleotide analogue uridine-triphosphate (SOF-007TP), which further gets de-phosphorylated to form predominant sofosbuvir inactive metabolite- GS-331007 (SOF-007).

The plasma protein binding of sofosbuvir is $82 \%$ in healthy subjects, whereas it is $85 \%$ in patients of ESRD. However, plasma protein binding of SOF-007 is minimal in healthy adults ${ }^{(31)}$. The median plasma half-lives of sofosbuvir and SOF-007 are 25 mins and 27 hours respectively ${ }^{(32)}$. Finally, SOF-007 is eliminated through kidneys, the renal clearance of which is around two-fold higher than glomerular filtration rate, which suggests that excretion occurs by tubular secretion as well.

Experience with sofosbuvir in patients with eGFR $<30 \mathrm{~mL} /$ $\min / 1.73 \mathrm{~m}^{2}$ is limited. Many studies have evaluated full dose, as well as full dose on alternate days, and half daily dose of sofosbuvir in this difficult-to-treat group (ESRD patients), but the data are very limited with no clear recommendations of its use.

In our study, we have included only Stage 5 CKD i.e. ESRD patients who were on HD with chronic HCV infection and who had no evidence of cirrhosis. We have used full dose of sofosbuvir (400 mg) along with combination therapy according to the HCV genotype. daclatasvir at a dose of $60 \mathrm{mg}$ was used for patients with infection with $\mathrm{HCV}$ genotype 2 and 3 , whereas ledipasvir 90 $\mathrm{mg}$ was used for $\mathrm{HCV}$ infection with genotype 1 and 5. In most studies, commonest genotype was 1 . In the present study also, majority of patients belonged to HCV genotype 1 in 12 (66.7\%), followed by genotype 3 in $4(22.3 \%)$ patients.

Virologic response i.e. SVR 12 was achieved in $100 \%$ of our enrolled patients. Similar result was seen in an Indian study by Taneja et al. where sofosbuvir was used at half the standard dose 
i.e. $200 \mathrm{mg}$ along with daclatasvir $60 \mathrm{mg}$ for all patients irrespective of $\mathrm{HCV}$ genotype. In this study out of 65 patients, $32 \%$ of patients had evidence of cirrhosis and $15.4 \%$ were treatment experienced ${ }^{(33)}$. Majority (64.6\%) patients belonged to HCV genotype 1, followed by genotype 3 in 34\% and genotype 2 in $1.4 \%$. All patients tolerated the DAAs well with none of the patients reporting any serious adverse events. Minor side effects were noted in the form of nausea, seen in $7.7 \%$ patients, insomnia and headache in $6.2 \%$ patients each, and pruritus in $1.5 \%$ patient.

Another report from India included 62 treatment naïve ESRD patients with chronic HCV infection which showed an SVR 12 in $95.2 \%$ patients $^{(1)}$. Genotype 1 was the most common in $64.5 \%$ of cases, followed by genotype 3 in $29 \%$ of cases. Thirty-nine patients were treated with sofosbuvir every other day with ribavirin, two patients with sofosbuvir daily with ribavirin, six with sofosbuvir every other day with daclatasvir, and 15 patients with sofosbuvir daily with daclatasvir. Three patients relapsed after completion of therapy who were on $400 \mathrm{mg}$ alternate day sofosbuvir treatment, suggesting that sofosbuvir dose may be an important variable for SVR.

Singh et al. reported an SVR in $95.7 \%$ of patients with $\mathrm{HCV}$ and CKD despite using full dose of sofosbuvir along with daclatasvir or ledipasvir based on HCV genotype. Their study group included 47 patients, out of which $25.5 \%$ were HCV with cirrhosis and $15 \%$ were decompensated cirrhotic with ascites ${ }^{(34)}$. All patients with cirrhosis achieved SVR 12, however, two patients in whom SVR 12 could not be demonstrated got re-infected due to ongoing dialysis as evident by infection with different genotype. The distribution of HCV genotype was genotype 1 in $68.1 \%$, genotype 3 in $27.7 \%$ and genotype 4 in $4.3 \%$ patients.

Few small case series have suggested that full-dose sofosbuvir is safe and efficacious in patients with severe renal insufficiency ${ }^{(35)}$. The large HCV-TARGET cohort suggested that though renal dysfunction did not affect SVR rates, baseline renal dysfunction increased the risk of side effects including anemia and worsening renal function in CKD patients treated with regimens containing full dose sofosbuvir.

With full dose sofosbuvir we did not find any significant difference between pre- and post-treatment levels of hemoglobin $(P=0.429)$ and eGFR $(P=0.788)$. Side effects which were minor and self-limiting were observed in seven patients, in form of nausea and dyspepsia in $4(22.2 \%)$ patients, fatigue in $2(11.1 \%)$ patients and headache in $1(5.5 \%)$ patient. However, all these symptoms could not be directly attributed to DAA therapy as these patients were having uremia and some had uncontrolled hypertension despite use of adequate anti-hypertensive medications. None of the patients required an increase in erythropoietin dosage. The most important observation was that none of the patients had any cardiovascular or hepatobiliary adverse events, though concerns regarding its safety profile have been raised in preclinical animal studies.

In a similar study by Surendra et al. in ESRD patients with chronic HCV infection with genotype 1, it was seen that combination of sofosbuvir and ledipasvir, on alternate days, is safe and effective $^{(36)}$. Rapid virologic response (RVR) was achieved in all $21(100 \%)$ patients enrolled in their study. After excluding two patients who died during the study, sustained virologic response after 12 weeks of completion of therapy (SVR 12) was achieved in all 19 patients.

In the HCV-TARGET study a total of 1789 patients with chronic hepatitis $\mathrm{C}$ infection were included and 18 individuals had eGFR less than $30 \mathrm{~mL} / \mathrm{min}$ and five were on HD. These patients were treated with various combinations of sofosbuvir / simeprevir, sofosbuvir / simeprevir / ribavirin, sofosbuvir / ribavirin, or sofosbuvir / pegylated interferon / ribavirin and demonstrated that $82 \%$ to $83 \%$ of patients achieved a SVR 12 with no significant differences observed between regimens ${ }^{(37)}$.

Desnoyer et al. treated eight patients with sofosbuvir and daclatasvir with four patients on daily full dose sofosbuvir and four on thrice weekly sofosbuvir for 12 or 24 weeks. Interestingly, seven of these patients had cirrhosis. They reported relapse in two patients who had cirrhosis and were treated for 12 weeks with thrice weekly regimen. Based on their data, authors recommended daily full dose sofosbuvir in patients who are treatment experienced or have liver cirrhosis. However, it is possible that the relapse in these two patients was due to the shorter duration of treatment rather than thrice weekly regimen, since another patient with cirrhosis, treated for 24 weeks, achieved SVR with thrice weekly regimen ${ }^{(38)}$. Moreover, the authors found that sofosbuvir or its inactive metabolite sofosbuvir-007 did not accumulate with either regimen between hemodialysis sessions or throughout the treatment course, and sofosbuvir was well tolerated by all patients.

The limitations of our study are: firstly, small sample size, thus interpreting percentage of side-effects our patients had during treatment, might get distorted, secondly study was a single center one, thirdly blood levels of sofosbuvir and its metabolites were not taken into consideration because of lack of resources and facilities. However, none of our patients had significant adverse events following treatment, which we could have attributed to the drug or its metabolite. Other parameters of renal dysfunction, for e.g. urine albumin-creatinine ratio or 24-hour urine protein excretion was not evaluated in these patients, the same should be looked for in future studies along with change in parameters in post treatment period.

Large-scale randomized studies are needed to explore the pharmacokinetics which includes optimal dosing, safety, and efficacy, in ESRD patients, with an emphasis on the stage of liver disease, to determine the optimal dose and duration of sofosbuvir based combination therapy in this population.

Our study is the first of its kind, in which only stage 5 CKD or ESRD patients on maintenance hemodialysis with chronic $\mathrm{HCV}$ infection were included. Full dose sofosbuvir (400 mg) in combination with daclatasvir $60 \mathrm{mg}$ or ledipasvir $90 \mathrm{mg}$ showed excellent results in terms of efficacy as well as safety in this difficult-to-treat population. With the prescribed regimen, SVR 12 rate in our study population was $100 \%$ with no significant deterioration in renal function as evaluated by eGFR or worsening of anemia in this population. Hence, we recommend that full dose sofosbuvir in combination with NS5A inhibitor can be safely used in ESRD patients.

\section{Authors' contribution}

Debnath P: planning of study, collection of data, writing of text. Chandnani S: survey execution, statistical analysis. Rathi P: supervision of study, study planning. Nair S: data collection, maintenance of records. Pawar V: scrutinisation of data. Contractor Q: study supervision, text writing.

\section{Orcid}

Prasanta Debnath: 0000-0001-8294-2031.

Sanjay Chandnani: 0000-0001-8270-7680.

Pravin Rathi: 0000-0002-1095-3652.

Sujit Nair: 0000-0002-2993-7353.

Vinay Pawar: 0000-0003-2633-2102.

Qais Contractor: 0000-0001-7191-8589. 
Debnath P, Chandnani S, Rathi P, Nair S, Pawar V, Contractor Q. Terapia inibidora de nucleotídeo NS5A\& NS5B combinada para pacientes com hepatite C crônica com doença renal crônica em estágio 5, em hemodiálise. Arq Gastroenterol. 2020;57(1):39-44.

RESUMO - Contexto - A infecção pelo vírus da hepatite C (HCV) é a infecção viral hepática mais comum que afeta pacientes em hemodiálise de manutenção. $\mathrm{O}$ tratamento da infecção crônica por HCV no estágio 4 e 5 da doença renal crônica inclui uma combinação de elbasvir/grazoprevir e glecaprevir/pibrentasvir, que não estão disponíveis em muitos países. Objetivo - Portanto, realizamos este estudo para procurar a segurança e eficácia da terapia combinada de sofosbuvir nesta população de difícil tratamento. Métodos - Realizamos um estudo de centro único, prospectivo e aberto, no qual pacientes com doença renal crônica em estágio 5 em hemodiálise de manutenção com infecção por HCV. Um total de 18 pacientes foi incluído. Sofosbuvir com daclatasvir ou ledipasvir foi usado de acordo com o genótipo por 12 semanas. O HCV RNA, genótipo, elastografia transitória foi considerado para cada paciente. O HCV RNA foi quantificado na $4^{\mathrm{a}}$ semana, $12^{\mathrm{a}}$ semana e 12 semanas após o tratamento para procurar uma resposta virológica sustentada. Resultados - A infecção por genótipo 1 foi observada em 12 (66,7\%) pacientes, seguido pelo genótipo 3 em 4 (22,3\%), em um paciente do genótipo 2 e em outro, 5 . O valor mediano do HCV RNA foi de $2.35 .000 \mathrm{IU} / \mathrm{mL}$. Na elastografia transitória, todos tinham rigidez hepática de $<9.4 \mathrm{KPa}$. Todos os pacientes tinham RNA HCV $<15 \mathrm{IU} / \mathrm{mL}$ na $4^{\mathrm{a}}$ e $12^{\mathrm{a}}$ semana de tratamento e 12 semanas após o tratamento. Não foi observada nenhuma alteração significativa na hemoglobina, eGFR e rigidez hepática. Conclusão - A dose completa sofosbuvir ou seja, $400 \mathrm{mg}$, em combinação com inibidores NS5A daclatasvir ou ledipasvir foi considerada segura e eficaz em pacientes com doença renal em estágio final, que estão em manutenção hemodiálise.

DESCRITORES - Hepacivirus. Diálise renal. Sofosbuvir. Técnicas de imagem por elasticidade.

\section{REFERENCES}

1. Agarwal SK, Bagchi S, Yadav RK. Hemodialysis patients treated for hepatitis C using a sofosbuvir-based regimen. Kidney Int Rep. 2017;2:831-5.

2. Ladino M, Pedraza F, Roth D. Hepatitis C Virus Infection in Chronic Kidney Disease. J. Am. Soc. Nephrol. 2016;27:2238-46.

3. Agarwal SK, Dash SC, Gupta S, Pandey RM. Hepatitis C virus infection in haemodialysis: the 'no-isolation' policy should not be generalized. Nephron. Clin. Pract. 2009;111:c133-40.

4. Finelli L, Miller JT, Tokars JI, Alter MJ, Arduino MJ. National surveillance of dialysis-associated diseases in the United States, 2002. Semin. Dial. 2005;18:52-61.

5. Fissell RB, Bragg-Gresham JL, Woods JD, Jadoul M, Gillespie B, Hedderwick $\mathrm{SA}$, et al. Patterns of hepatitis $\mathrm{C}$ prevalence and seroconversion in hemodialysis units from three continents: The DOPPS. Kidney Int. 2004;65:2335-42.

6. Selcuk H, Kanbay M, Korkmaz M, Gur G, Akcay A, Arslan H, et al. Distribution of HCV genotypes in patients with end-stage renal disease according to type of dialysis treatment. Dig Dis Sci. 2006;51:1420-5.

7. Jasuja S, Gupta AK, Choudhry R, Kher V, Aggarwal DK, Mishra A, et al. Prevalence and associations of hepatitis $\mathrm{C}$ viremia in hemodialysis patients at a tertiary care hospital. Indian J Nephrol. 2009;19:62-7.

8. Di Napoli A, Pezzotti P, Di Lallo D, Petrosillo N, Trivelloni C, Di Giulio S. Epidemiology of hepatitis $\mathrm{C}$ virus among long-term dialysis patients: A 9-year study in an Italian region. Am J Kidney Dis. 2006;48:629-37.

9. Sun J, Yu R, Zhu B, Wu J, Larsen S, Zhao W. Hepatitis C infection and related factors in hemodialysis patients in china: Systematic review and meta-analysis. Ren Fail. 2009;31:610-20.

10. Agarwal SK, Mohan MP, Varghese M. Assessment of awareness regarding universal precaution among the nursing staff of AIIMS in 1997. J AssocPhy India. 1998;46:1061.

11. Alavian SM, Kabir A, Ahmadi AB, Lankarani KB, Shahbabaie MA, Ahmadzad-Asl M. Hepatitis C infection in hemodialysis patients in Iran: A systematic review. Hemodial Int. 2010;14:253-62.

12. Fabrizi F, Dixit V, Dixit V. Impact of hepatitis C on survival in dialysis patients: A link with cardiovascular mortality? J Viral Hepat. 2012;19:601-7.

13. Singh N, Neidlinger N, Djamali A, Leverson G, Voss B, Sollinger HW, Pirsch JD. The impact of hepatitis $\mathrm{C}$ virus donor and recipient status on long-term kidney transplant outcomes: University of Wisconsin experience. Clin Transplant. 2012;26:684-93.

14. Casanovas Taltavull T, Baliellas Comellas C, Cruzado Garrit JM. Results of hepatitis $\mathrm{C}$ virus treatment in patients on hemodialysis: Data from published meta-analyses in 2008. Transplant Proc. 2009;41:2082-4.

15. Rendina M, Schena A, Castellaneta NM, Losito F, Amoruso AC, Stallone G, et al. The treatment of chronic hepatitis $\mathrm{C}$ with peginterferon alfa-2a $(40 \mathrm{kDa})$ plus ribavirin in haemodialyzed patients awaiting renal transplant. J Hepatol. 2007;46:768-74.

16. Fabrizi F, Messa P, Basile C, Martin P. Hepatic disorders in chronic kidney disease. Nat Rev Nephrol. 2010;6:395-403.
17. Duseja A, Choudhary NS, Gupta S, Dhiman RK, Chawla Y, Sakhuja V. Treatment of Chronic Hepatitis $\mathrm{C}$ in end stage renal disease: Experience at a tertiary care centre. Trop Gastroenterol. 2012;33:189-92.

18. Gordon CE, Uhlig K, Lau J, Schmid CH, Levey AS, Wong JB. Interferon treatment in hemodialysis patients with Chronic Hepatitis $\mathrm{C}$ virus infection: A systematic review of the literature and meta-analysis of treatment efficacy and harms. Am J Kidney Dis. 2008;51:263-77.

19. Alavian SM, Tabatabaei SV. Meta-analysis of factors associated with sustained viral response in patients on hemodialysis treated with standard or pegylated interferon for hepatitis C infection. Iran J Kidney Dis. 2010;4:181-94.

20. Okoh EJ, Bucci JR, Simon JF, Harrison SA. HCV in patients with end-stage renal disease. Am J Gastroenterol. 2008;103:2123-34.

21. Carrion AF, Fabrizi F, Martin P. Should ribavirin be used to treat hepatitis $\mathrm{C}$ in dialysis patients? Semin Dial. 2011;24:272-4.

22. Liu C-H, Huang C-F, Liu C-J, Dai CY, Liang CC, Huang JF, et al. Pegylated interferon- $₫ 2 \mathrm{a}$ with or without low-dose ribavirin for treatment-naive patients with hepatitis $\mathrm{C}$ virus genotype 1 receiving hemodialysis. Ann Intern Med. 2013; 159:729.

23. AASLD-IDSA. Recommendations for testing, managing, and treating hepatitis C. Available from: http:// www.hcvguidelines.org.

24. Roth D, Nelson D, Bruchfeld A, Liapakis A, Silva M, Monsour H Jr, et al. Grazoprevir plus elbasvir in treatment-naive and treatment experienced patients with hepatitis $C$ virus genotype 1 infection and stage $4-5$ chronic kidney disease (the C-SURFER study): A combination phase 3 study. Lancet. 2015;386:1537-45.

25. Pockros PJ, Reddy KR, Mantry PS, Cohen E4, Bennett M5, Sulkowski MS, et al. Efficacy of Direct-Acting Antiviral Combination for Patients With Hepatitis C Virus Genotype 1 Infection and Severe Renal Impairment or End-Stage Renal Disease. Gastroenterology. 2016;150:1590-8.

26. Gane E, Lawitz E, Pugatch D, Papatheodoridis G, Bräu N, Brown A, et al. Glecaprevir and Pibrentasvir in patients with $\mathrm{HCV}$ and severe renal impairment. $\mathrm{N}$ Engl J Med. 2017:377:1448-55.

27. Sofosbuvir For Treatment of Chronic Hepatitis C Infection. 2013. Available from: http://www.natap.org/2013/HCV/20131 025-AVDAC-B1-02-Gilead.pdf.

28. Gane EJ, Robson RA, Bonacine M, Maliakkal B, Kirby B, Liu L, et al. Safety, antiviral efficacy, and pharmacokinetics of sofosbuvir in patients with severe renal impairment. In: 65th annual meeting of the American association for the study of liver diseases, 7 Nov 2014. Boston, MA; 2014.

29. AASLD-IDSA. Recommendations for testing, managing, and treating hepatitis C. Available from: http:// www.hcvguidelines.org.

30. Association for the Study of the Liver. EASL Recommendations on Treatment of Hepatitis C 2016. J Hepatol. 2016; Available from: http://www.easl.eu/media s/cpg/HCV2016/English-report.pdf.

31. Kirby BJ, Symonds WT, Kearney BP, Mathias AA. Pharmacokinetic, Pharmacodynamic, and Drug-Interaction Profile of the Hepatitis C Virus NS5B Polymerase Inhibitor Sofosbuvir. Clin Pharmacokinet. 2015;54:677-90. 
32. Sovaldi. 2015. Sofosbuvir. Summary of Product Characteristics, Gilead Sciences, Hayes, UK Food \& Drug Administration. Available at: http://www.accessdata fda.gov/drugsatfda_docs/label/2015/204671s004lbl.pdf.

33. Taneja S, Duseja A, De A, Mehta M, Ramachandran R, Kumar V, et al. Low-Dose Sofosbuvir Is Safe and Effective in Treating Chronic Hepatitis C in Patients with Severe Renal Impairment or End-Stage Renal Disease. Dig Dis Sci. 2018;63:1334. Available from: https://doi.org/10.1007/s10620-018-4979-6.

34. Singh A, Kumari S, Kumar P, De A, Singh V. Sofosbuvir with NS5A inhibitors in hepatitis $\mathrm{C}$ virus infection with severe renal insufficiency. J Viral Hepat. 2018. doi: $10.1111 /$ jvh.12983.
35. Gevers TJG, Burger D, Schipper-Reintjes E, Kooistra MP, Richter C. Full-dose Sofosbuvir and Daclatasvir for Chronic Hepatitis C infection in haemodialysis patients. Neth J Med. 2016;74:225-7.

36. Surendra M, Raju S, Sridhar N, Vijay Kiran B, Rajesh G, et al. Ledipasvir and Sofosbuvir for untreated HCV genotype 1 infection in end stage renal disease patients: A prospective observational study. Hemodial Int. 2018;22:217-21.

37. Saxena V, Koraishy FM, Sise ME, Lim JK4, Schmidt M5, Chung RT, et al. Safety and efficacy of sofosbuvir-containing regimens in hepatitis $\mathrm{C}$-infected patients with impaired renal function. Liver Int. 2016;36:807-16.

38. Desnoyer A, Pospai D, Lê MP, Gervais A, Heurgué-Berlot A, Laradi A, et al Pharmacokinetics, safety and efficacy of a full dose sofosbuvir-based regimen given daily in hemodialysis patients with chronic hepatitis C. J Hepatol. 2016;65:40-7. 